and also surgically with the object of restoring both respiration and circulation to normal after the injury. In such cases the treatment of shock is equally important.

Zusammenfassung. Von den Autoren wird ein Krankengut von 682 Thoraxtraumen angeführt, unter denen sich 68 Lungen- und Bronchialtraumen, 5 Herztraumen und 10 traumatische Beschädigungen der Aorta thoracalis befanden. Die Autoren betonen, daß stumpfe Thoraxtraumen $\mathrm{zu}$ sehr verschiedenartig klinischen Symptomen führen, bei denen die konservative und auch operative Behandlung mit dem Ziel durchgeführt wird, die Atmung und den Kreislauf nach dem Trauma zu normalisieren. Die Schockbekämpfung ist dabei von gleichgroßer Wichtigkeit.

\title{
229. Operative Möglichkeiten beim Bronchus-Chondrom
}

\author{
J. KoKaLJ*, J. DRŽEČNIK und VRŠČAJ-Maribor/Jugoslawien
}

\section{Possible Operations for Bronchial Chondroma}

Summary. A very rare tumour, chondroma of the left main bronchus, was seen in an adolescent. Although symptoms and atelectases had been present for some time, it was possible to remove the tumour by simple bronchotomy after typical left thoracotomy without sacrificing any lung tissue. The result was excellent. Other therapeutic possibilities are discussed.

Zusammentassung. Bei einem Jugendlichen wurde ein ganz seltener Tumor, Chondrom im linken Hauptbronchus beobachtet. Trotz länger dauernder Symptomatologie mit Atelektasen gelang es durch eine einfache Bronchotomie, durchgeführt durch die typische linksseitige Thorakotomie, den Tumor zu entfernen, ohne Lungengewebe opfern zu müssen. Das Resultat ist ausgezeichnet. Die anderen therapeutischen Möglichkeiten werden noch besprochen.

\section{Erweiterte Indikationsstellung zur Rekonstruktion der Beckenarterien in Lokalanaesthesie}

\section{G. BaUMaVN-München}

\section{Extended Indication Range for the Reconstruction of the Pelvic Arteries under Local Anaesthesia}

Summary. It is possible in the case of very elderly patients, or those who are in a very poor general state of health, to remove an occlusion of the pelvic artery retrograde from the arteria femoralis communis. This operation can be carried out under local anaesthesia. One has to take care to free a sufficiently long section of the arteria femoralis communis and then attach it in two places. Rubber tourniquets and not clamps should be used to secure the vessel.

This method was used in 53 patients, who were mostly 60-80 years of age. The operation succeeded in 51 cases. Perforation of the artery occurred on 2 occasions, so that a Dacron implant had subsequently to be used. In one patient the occlusion recurred. Two patients died from other causes.

Though this method has not been adopted as a routine procedure, it is eminently suitable in special "at risk" cases, where a threatened amputation can be avoided. 